\title{
LARGE SCALE MAGMATIC BANDING IN MESOZOIC BASIC SILL. OF THE PARANÁ BASIN, CAMPINAS, SÃO PAULO STATE, BRAZIL.
}

Elson P. Oliveira, Luciana Sato, Luiz Cesar Correa Gomes and Guttenberg Martins

Instituto de Geociências, UNICAMP, 13081-970 Campinas, Brazil

The recognition of layered primary structures in basic intrusions helps not only to understand magmatic processes within magma chambers but also to evaluate their metallogenic potential. Here, we briefly describe an occurrence of large scale magmatic banding in a basic sill of the Basalto Quarry (former Pedralix) at kilometre 2.3 of the Campinas - Monte Mor motorway. As far as we are concerned, this is the the first occurrence of inequivocal magmatic banding in basic intrusions of the Paraná continental flood basalt province.

The igneous banding is largely given by sub-horizontal sheets of very coarse-grained gabbro interleaved with dominantly middle- to fine-grained diabase to basalt (Fig. 1 - for scale note a man at the lower ground centre). The pegmatitic gabbro is lighter in colour (Fig.1) than the diabase (a feature enhanced on weakly weathered outcrops) and consists of laterally discontinuous lenses ranging from a few centimetres to 6 metres thick (mostly in the range 1.5 to 2.0 metres) and several tens of metres in length. From the hanging-wall contact with Palaeozoic sediments to the quarry's deepest level (ca. $60 \mathrm{~m}$ ), the lenses thickness increases and their shape becomes more irregular. The contact between pegmatitic gabbro and basalt-diabase is sharp but no chilled margin of one rock type against the other has been observed so far. They are mineralogically composed of olivine, calcic pyroxene, plagioclase and accessory iron-titanium oxide and apatite.

Whole-rock chemistry clearly indicates that the pegmatitic gabbroic lenses are geochemically more evolved than the associated basalt-diabase (e.g.4.06-3.18\% MgO, 3.94-3.91\% TiO2, 0.37-0.49\% P2O5, 229-255 ppm $\mathrm{Zr}, 23-29 \mathrm{ppm} \mathrm{Nb}$ in the former as opposed to 4.79-5.51\% MgO, 2.74-2.57\% TiO2, 0.31-0.35\% P2O5, $167-182 \mathrm{ppm}$ $\mathrm{Zr}, 18 \mathrm{ppm} \mathrm{Nb}$ in the latter). As yet, the available mineral chemical data do not indicate any significant compositional variation between similar minerals of the two dominant rock types.

Conformable or semi-conformable pegmatitic gabbro sheets are not uncommon in layered mafic intrusions and flows (e.g. Larsen \& Brooks 1994, Philpotts et al. 1996), where they are generally thought to have crystallized from segregated liquids injected into dilational fractures formed in incompletely solidified rocks. Whether this mechanism may account or not for the magmatic features observed in the Basalto Quarry requires further studies. Finally, if the pegmatitic gabbro sheets prove to be late stage differentiates of basalt-diabase, as the chemical variation referred to above indicates, then one may raise the possibility that accumulation of minerals might have taken place somewhere in the magma chamber, with important implications for mineral exploration in the Paraná continental flood basalt province.

\section{References}

LARSEN, R.B., BROOKS, C.K. (1994) Origin and evolution of gabbroic pegmatites in the Skaergaard intrusion, East Greenland. Journal of Petrology, 35: 1651-1679.

PHILPOTTS, A.R., CARROLL, M., HII.L, J.M. (1996) Crystal-mush compaction and the origin of pegmatitic segregation sheets in a thick flood-basalt flow in the Mesozoic Hartford basin, Connecticut. Journal of Petrology, 37: 811-836.

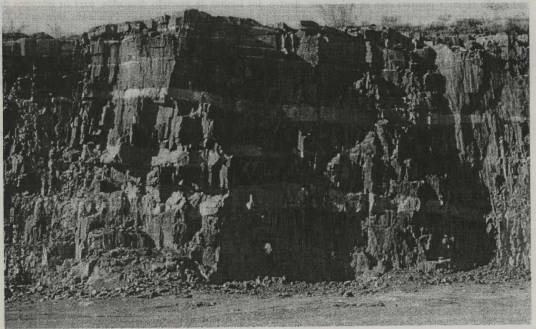

